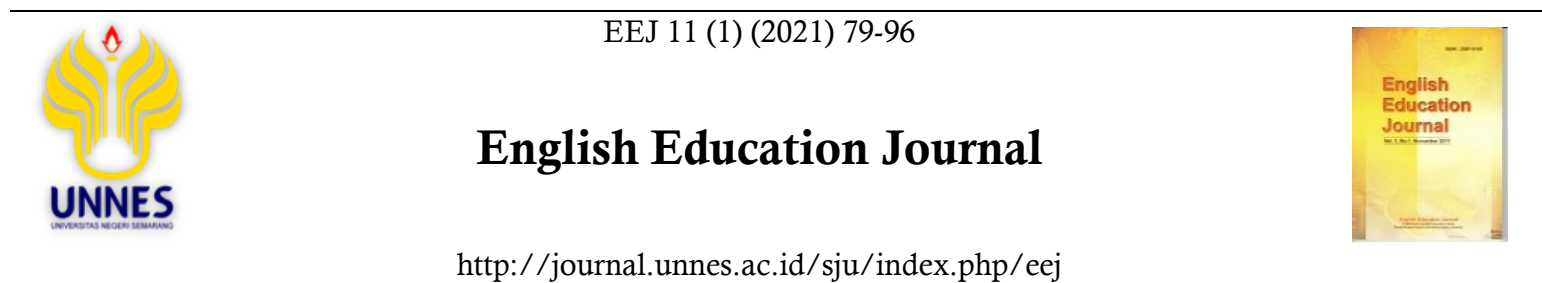

\title{
Evaluating The Quality of The Indonesia-English Translation of Research Abstracts Written By The Students Of Harapan Bangsa University
}

\author{
Ida Dian Sukmawati ${ }^{1 凶}$, Rudi Hartono $^{2}$, Djoko Sutopoo $^{2}$ \\ 1. Universitas Harapan Bangsa, Indonesia \\ 2. Universitas Negeri Semarang, Indonesia
}

\begin{tabular}{l}
\hline Article Info \\
\hline Article History: \\
Accepted 27 \\
September 2020 \\
Approved 07 \\
December 2020 \\
Published 15 March \\
2021
\end{tabular}

Keywords:

Abstract, Translation Ideology, Translation Quality

\begin{abstract}
This study was focused on evaluating the quality of the Indonesian-English translation of the research abstract written by the students of Harapan Bangsa University. The analysis included the analysis of translation quality in terms of accuracy, naturalness, acceptability, and readability as well as the translation ideology. The results of the study showed that the accuracy of the research abstract translation was dominated by highly accurate translation and less accurate translation in the target language which shared the same percentage as many as $36 \%$. In terms of naturalness, it showed that $34 \%$ of the translation was categorized into highly natural. With regard to translation acceptability, it showed that $61 \%$ of the data belonged to acceptable. Meanwhile, in terms of translation readability, it showed that $75 \%$ of the data was categorized as readable. The register and genre of the research abstract texts and its translation were kept equivalent and holding the same purposes as it was translated overtly. In translating the research abstract text, it is suggested that the translator could highly consider the accuracy, naturalness, acceptability, and readability of the translation, particularly for target readers. With regard to the translation ideology, the translator is suggested to grasp the register and genre of the text before the translation process and regard the target readers to determine whether the text should be translated covertly or overtly.
\end{abstract}

\footnotetext{
Correspondence Address:

Jl. Raden Patah No.100, Kedunglongsir, Ledug, Kec. Kembaran,

Kabupaten Banyumas, Jawa Tengah 53182

p-ISSN 2087-0108

E-mail: idadian.shb@gmail.com

e-ISSN 2502-4566
} 


\section{INTRODUCTION}

Translation has become a major means of communication among the people where people live in a multilingual world. By transferring the information from one language to another language, it enables the people to establish a relationship among nations. Larson (1984) stated that translation consists of transferring the meaning of the source language into the receptor language (p.3). This is done by going from the form of the first language to the form of a second language by way of semantic structure. It is meaning which is being transferred and must be held constant. While according to Bassnet (1998) translation is the rendering of a source language text into the target language (p.2). It means that when doing the translation process, a translator has to ensure that the surface meaning of source language and target language will be approximately similar. Besides, the structures of the SL will be preserved as closely as possible but not so close that the TL structure will be seriously distorted

An abstract is a shortened version of a paper. It is a summary of the most important points in a scientific paper. It is also a summary of a research article, thesis, review, conference proceeding, or any in-depth analysis of a particular subject and is often used to help the reader quickly ascertain the paper's purpose. Abstracts enable professionals to stay current with the huge volume of scientific literature. An abstract may act as a stand-alone entity instead of a full paper. The typical length of abstract ranges from 200 to 250 words, but rarely more than a page. In the application, an abstract always appears at the beginning of a manuscript or typescript which is always provided both in the original language and English as international language, because it will help international reader to understand the research. However, providing an abstract in two language sometimes could bring to confusion for the readers when mistakes occur during the translation process (Arono \& Nadrah, 2019).

Writing abstract is a compulsory part in composing a research, especially for university students. In the nursing department of Harapan Bangsa University, the nursing students were given a course named English for academic purposes in semester 8 to prepare them in composing a research as well as the abstract. In this course, the students not only get academic writing but also translation. Thus, they are expected to translate the research abstract in a good form (Fitria, 2018 and Napitupulu, 2017).

However, in order to fulfill the requirement to write an abstract in Indonesia and English, the students of Harapan Bangsa University, especially from the nursing department, translate their research abstract by themselves, and apparently, some students ask somebody else or translator to translate their research abstract. The translator who requested to translated might not a medical translator either because many of them do not focus on one kind of text but all kinds of text. On one hand, they are facing a big responsibility because the result of their translation can significantly influence someone's health and medical condition because of most of the research article made by the nursing students of Harapan Bangsa University dealing with human health or medical condition. In other words, producing a bad translation of the medical text can lead to misinterpretation or misunderstanding of the facts that have been discovered by the students as the researcher. Since the translation of the abstract of the nursing student's research article is influenced to someone's health as the reader of the abstract, it is important to evaluate the Quality of the Indonesia-English Translation of Research Abstract Written by the Students of Harapan Bangsa University.

In doing a translation job, there will some problems arise since sameness cannot exist between two languages (Bassnett, 2002, p.38). The translator cannot just transfer one language to another language. Linguistic or extralinguistic aspects of the languages will affect the translator in the translation process. It leads to problems that will interrupt the translator to transfer the meaning of the source language to the target language. Nida (1975) categorized difficulties which become translation problems 
into an ecological problem, social culture, material culture, religious culture, and linguistic culture (p.34). Concerning the linguistic elements, the translation unit covers the individual word, group, clause, sentence, or even the whole text, when working on the source text (Hatim and Munday, 2004, p.17). The level of difficulty in translating the units of translation is influenced by the unit type, for example in translating the text; the translator will find various kinds of problems that challenge the translator to find the equivalence in the target language. Hence, various translators have their own strategies and style in translation to recreate the text into the target language.

In order to encapsulate the ways different perspectives about the evaluation of translation work by the assessor to evaluate objectively and effectively the quality of the final translation work, the translation quality assessment is undoubtedly needed. Furthermore, to improve the translation quality and to know whether the translated work is good or bad, its quality should be assessed (Kamil, 2014; Barezzi et al., 2018; and Admiati and Hartono, 2019). High quality of translation is achieved when the translation product meets certain standards and criteria. According to Schaffner (1998), translation quality assessment includes the process of comparing the target text (TT) to the source text (ST) to see whether the TT is an accurate, correct, precise, faithful, or true reproduction of the ST (p.1).

Evaluating the quality of translation work has been one of the main concerns of translation studies recently. Many experts are emphasizing the importance of translation quality assessment in order to promote a good translation product. Larson (1984) mentioned that there were some aspects to evaluate the translation quality, namely: accuracy, naturalness, naturalness, and readability. Moreover, House (2015) proposed a translation quality model that relies on detailed textual and culturally informed analysis and comparison. House's 2015 model is a leading model in the field of TQA that places ST analysis and its comparison with the TT at its heart. According to House (2015) Translation should be able to transfer a text in the source language into the target language by a semantically and pragmatically equivalent one (p.23). Furthermore, the analysis leads to the ideology followed by the translators whether the translation is overt or covert. This indicates that translation of a text should be assessed based on semantic and pragmatic perspectives in order to reproduce the equivalent translation for target readers (Zainudin and Awal, 2012; Yuliasri and Hartono, 2014).

There have been some previous studies discussing evaluating translation works in various kinds of objects, particularly academic text. Hartono and Priatmojo (2016) found out that translation quality is regarded as poor translation when did not meet translation accuracy, naturalness, and readability. However, there are still few studies dealing with how academic text is viewed by House's translation quality assessment. It is a plausible fact since the analysis is quite updated as it was proposed in 2015. Therefore, this study tried to reveal the quality of the translation of the research abstract and to explain the ideology used in abstract translation.

\section{METHODS}

The design of this study was descriptive qualitative study which aimed to evaluate the translation quality of research abstract text. This study focused on the accuracy, naturalness, acceptability and readability translation. In addition, the focus also goes into the analysis of translation quality assessment proposed by Fiederer and O'Brian (2009) for translation accuracy and naturalness; and Nababan (2012) for translation acceptability and readability. Finally, translation ideology was unveiled by the analysis of register and genre of the source text and target text.

\section{RESULTS AND DISCUSSIONS}

This study analysed the abstracts of nursing students from Harapan Bangsa 
University with 20 research abstract texts from academic year 2019 and 2020 which were taken randomly from the campus library. The abstract was taken from thesis of the bachelor/undergraduate degree students who had finished their study. The 20 research abstract texts were extracted into 246 sentences as the data analysis in terms of translation quality elements. The research abstract texts as well as the English version were compared and analysed based on the translation quality assessment in terms of four aspects, namely: accuracy, naturalness, acceptability and readability.

\section{Translation Accuracy}

In terms of accuracy, the translation was also assessed using Fiederer and O'Brian (2009) rating scale which categorize the accuracy category into four types of accuracy, namely highly accurate, accurate, less accurate and inaccurate. Here was the result of translation accuracy.



Figure 1. Translation Accuracy

As presented in Figure 1, there were 90 occurrences of highly accurate translation of research abstract text out of 246 data which made it as the highest category. Thus, the unique fact was that it was almost reached by less accurate translation. Meanwhile, there was only 13 data that was considered inaccurate translation. Most of the content of the translation was carried out accurately occurred only within 55 data. Furthermore, the example of highly accurate translation was provided in Table 1.
Table 1. Highly Accurate Translation

\begin{tabular}{|c|c|}
\hline $\mathrm{ST}$ & $\begin{array}{l}\text { Hipertensi menjadi penyakit yang perlu } \\
\text { mendapat perhatian khusus, agar tidak } \\
\text { menimbulkan komplikasi. }\end{array}$ \\
\hline $\mathrm{TT}$ & $\begin{array}{l}\text { Hypertension is a disease that needs } \\
\text { special attention, so it does not cause } \\
\text { complications }\end{array}$ \\
\hline
\end{tabular}

Table 1 showed that translation was regarded to have highly accurate translation as the translator has already transferred the meaning of the source sentence accurately by means of literal translation. Furthermore, the terminologies had already been transferred accurately such as hipertensi into hypertension, penyakit into disease, and komplikasi into complications. The sentence was also rendered by similar English grammatical rules which was matched with the Indonesian rules which made the translation able to maintain the meaning from the source language into target language.

With regard to the function of the sentence, the sample belonged to the introductory paragraph that inform the readers about the general phenomena as it was provided also with into present tense, although in Indonesian there is no grammatical rules to emphasize the tense used. Hence, the translator had already accurately rendered the sentence from the source text.

Meanwhile, the example of accurate translation was presented in Table 2.

Table 2. Accurate Translation

PT Perkembangan anak dapat terhambat apabila
lingkungan tidak mendukung seperti asupan
gizi yang tidak adekuat, kurang stimulasi, dan
tidak mendapatkan pelayanan kesehatan yang
memadai.
TT Children's development can be hampered
if they live in unsupportive environment
such as inadequate nutrition, lack of
stimulation, and inadequate health
services.

The example on Table 2 talked about the introductory paragraph of the research abstract. The sentence was accurately transferred into 
English, including the terminologies and the grammatical structure. The terminologies were almost completely transferred into English, such as terhambat into hampered, lingkungan tidak mendukung into unsupportive environment, asupan gizi yang tidak adekuat into inadequate nutrition, kurang stimulasi into lack of stimulation and pelayanan kesehatan yang tidak memadai into inadequate health services. Yet, there was only one terminology that was not accurately rendered, perkembangan anak into children's development although the meaning was still close to the correct meaning. Since the terminology refers to scientific term, it was supposed to be translated without addition of belonging. Hence, the term perkembangan anak was supposed to be translated into children development.

In term of grammatical structure, the sentence acted as general statement that had to be provided into present tense to represent its functions. Thus, the sentence had already proved that the function of the sentence had also been rendered into the target text which written in the form of present tense.

Moreover, the example of less accurate translation was provided in Table 3.

Table 3. Less Accurate Translation

ST Penelitian ini merekomendasikan
perlunya peningkatan kesadaran perawat
dalam mengelola seragam sebagai upaya
pencegahan terjadinya infeksi nosokomial
dengan cara mengganti seragam dan tidak
mencampurkan seragam dengan pakaian
lainnya ketika di cuci.
This research was recommend that
increase the nurse's behavior to keep the
uniform as the intervention to prevent the
nosocomial infection with washing the
uniform and un mixing the nurse's
uniform and with other clothes.

On Table 3, the data was categorized into less accurate translation because some factors. The terminologies used in the target language were not representing the meaning of the source language, such as: kesadaran perawat into the nurse's behavior and seragam into the nurse's uniform. The terminologies were not representing the same meaning as the source language, because the terminologies were classified as general words without determiners as the writer of the research abstract provided recommendation for general people. Hence the terminology the nurse's behavior should be replaced by nurse awareness. Likewise, the term the nurse' uniform should be replaced by nurse uniform which was also addressed to general nurse.

With regard to the grammatical structure of the sentence, there were some mistakes made by the translator who made the translation became less accurate. The use of voice which different from the source language in the sentence created ungrammatical sentence in the target language. The sentence penelitian ini merekomendasikan which was translated into this research was recommend should be replaced by this research recommended. Although the sentence voice could be changed into passive voice, there were some changes that need to be considered to do so. When it was going to be changed into passive voice, the sentence might be change into it was suggested from this study that in order to render the same meaning as the source language. Furthermore, the use of preposition dengan cara that was translated into with should be replaced by the words by to create accurate translation as delivered by the source language.

In addition, the example of inaccurate translation was provided in Table 4

Table 4. Inaccurate Translation

ST Hasil penelitian menunjukkan dengan
menggunakan spearman rank, untuk
variabel lingkungan kerja dikatakan baik
sebanyak 27 responden $(90.0 \%)$, untuk
variabel motivasi kerja dikatakan tinggi
sebanyak 25 responden $(83.3 \%)$, dan
untuk variabel kinerja dikatakan baik
sebanyak 27 responden $(90.0 \%))$.
TT -

Based on Table 4, this sentence was not transferred into the target language although this statement was regarded as important part of the 
research since it contained the supporting data as consisted within the research. Yet, the abstract translation only discussed the conclusion of the research. As the requirement of good abstract structure, the abstract have to be attached by the research result which are supported by data as the proof of the analysis. The translator did not render the sentence into the target language; instead, the translator left the translation blankly.

\section{Translation Naturalness}

Translation naturalness refers to the how easy the translation to be understood (Fiederer and O'Brian, 2009). The translation is deemed to have high naturalness when the target readers are able to fully understand the translation. Larson (1998, p.529) emphasised that translation naturalness constitutes that the text is easy to be read which is proved by the appropriate language style of the target language. The result of translation naturalness could be seen in Figure 2.

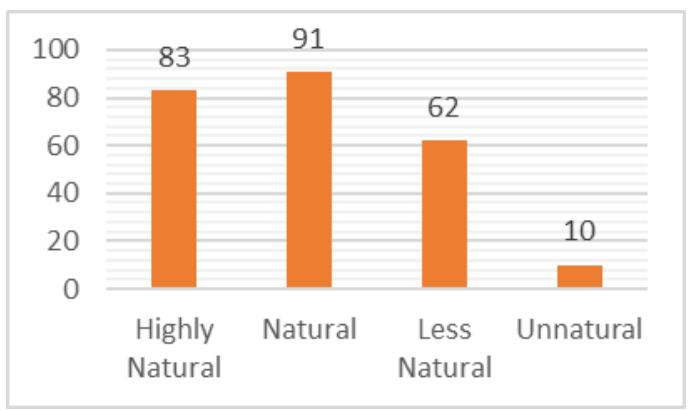

Figure 2. Translation Naturalness

Based on Figure 2, the naturalness translation category was dominated by natural category with 91 occurrences of the data. This indicated that most of the translation was mostly understandable in the target language. Meanwhile, there was only 10 occurrences of unnatural translation within the research abstract translation. The description of translation naturalness of the research abstract translation was provided in this following description.
Table 4. Highly Natural Translation

ST Penelitian ini bertujuan untuk mengetahui
hubungan sikap dan frekuensi
pemeriksaan gigi dengan status
kebersihan mulut pada siswa SD Negeri I
Karangjati Kemranjen Banyumas.
TT This study was aimed to investigate the
correlation between the attitude and the
frequency of dental checkup and the
status of oral hygiene of the students of
Karangjati State Elementary School I
Kemranjen Banyumas.

Based on Table 4, the sentence was regarded to accomplish highly natural translation as represented by the use of appropriate terminologies and the grammatical structure of the sentence. In terms of terminologies, the medical terminologies from the source language were clearly rendered into target language, such as sikap into the attitude, frekuensi pemeriksaan gigi into frequency of dental checkup, and status kebersihan mulut into status of oral hygiene. Those terminologies were considered highly natural since the equivalence of the words existed among source and target languages. Thus, the message consisted within the terminologies were received well for the target readers. Furthermore, there was a terminology that was translated literally which might sound not completely normal, such as $S D$ Negeri into State Elementary School. The concept of state elementary school might exist differently according to educational system the country followed. However, the translator helped the target readers by rendering the terminology using description. In addition, some of the proper names were left as it was for the sake of site identification of the research, such as Kemranjen and Banyumas. Hence, the terminologies did not create any ambiguity for the target readers.

With regard to the grammatical structure of the sentence in the table, it followed the past tense structure as the research had been done before the abstract was written. Moreover, the choice of the preposition had already been natural following the grammatical rules in the 
target language, such as correlation...between...and... This pair of prepositions was naturally used in English to express the correlation between two things. Furthermore, the function of the sentence was conveyed well in the target language that was informing the readers about the research being conducted.

Furthermore, the natural translation example was presented in Table 5.

Table 5. Natural Translation

ST Faktor lain yang dapat menunjang pelaksanaan praktek keperawatan secara profesional adalah dengan memperhatikan lingkungan kerja.

TT Another factor that can support the implementation of nursing practice professionally is paying attention to the work environment.

The sentence provided in Table 5 had reached the category of natural translation because the content of the sentence in the source language had already conveyed into the target text by means of medical terminologies and the grammatical structure of the sentence. The terminologies within the sentence were rendered naturally into the target language, such as pelaksanaan praktek keperawatan into implementation of nursing practice, secara professional into professionally, and lingkungan kerja into work environment. However, there was a bit ambiguity in the target language as it might conveyed different meaning. The phrase faktor lain yang dapat menunjang pelaksanaan praktek keperawatan secara professional that was translated into another factor that can support the implementation of nursing practice professionally yielded an ambiguity about which one was embedded by the word professional. According to the meaning of the sentence in the source language, the phrase that was embedded by the word professional was nursing practice, although the word secara profesional functioned as adverb. Furthermore, this small ambiguity could be overcome if the translation of the sentence faktor lain yang dapat menunjang pelaksanaan praktek keperawatan secara professional was translated into another factor that can support the implementation of professional nursing practice.

With regard to the grammatical structure of the sentence, it had also been translated naturally following the structure of the source language as it functioned as the introduction of the research and preliminary information for the target readers. The tense used was present tense, because the sentence informed the target readers about general thing although the source language did not mention it due to its grammatical structure. Furthermore, the translator had already understood how to arrange the words in the process of translation.

In addition, the less natural translation was provided in Table 6 .

Table 6. Less Natural Translation

\begin{tabular}{|c|c|}
\hline $\mathrm{ST}$ & $\begin{array}{l}\text { Bagi peneliti selanjutnya, supaya } \\
\text { bereksperimen dengan penambahan } \\
\text { frekuensi dan memperbaiki metode } \\
\text { monitoring pada saat melakukan Self } \\
\text { Tapping. }\end{array}$ \\
\hline & $\begin{array}{l}\text { For researcher furthermore, so that } \\
\text { experiment with increase frequency and } \\
\text { repair monitoring method, enough } \\
\text { moment performed Self Tapping. }\end{array}$ \\
\hline
\end{tabular}

As it could be seen on Table 6, the sentence was categorized as less natural translation because there were some terminologies that were not well transferred into the target language and also the grammatical structure that was still needed to be revised. The choice of diction in the target language did not clearly rendered into the target language which could not represent the real meaning of the source language. Although there were some terminologies that were translated naturally into the target language, such as peneliti into researcher, frekuensi into frequency, and metode monitoring into monitoring method, it was not enough to create natural translation. The terminology self tapping was supposed to be naturally translated to the target language become self-tapping with addition of dash (-) because it was a punctuation mark between parts 
of compound words and also the keyword of the research abstract. Furthermore, the word memperbaiki that was rendered into repair was not naturally translated considering the context of the sentence. It would be natural if the word was replaced by improve as the word has already carried the concept of repairment. In addition, the word selanjutnya was also translated unnaturally into furthermore that was conveying the different concept from the source language. The phrase untuk peneliti selanjutnya was supposed to be rendered into for further researcher in order to bring the equivalence from the source language.

In regard to the grammatical structure, there was some mistakes on the words arrangement which produced ambiguities for the target readers. The sentence did not contain any subject and verb as the requirement of a clause as the smallest unit of a sentence which indicated that the translator did not understand with the content of the source language. The ambiguity was also caused by the form of adjective phrase dengan penambahan frekuensi dan memperbaiki metode monitoring that was translated into with increase frequency and repair monitoring method. The translation could replace it by using gerund concept into by increasing frequency and improving monitoring method. Furthermore, the translator should be creatively rendered the sentence by rendering them into for further researcher, it is suggested to experiment by increasing frequency and improving monitoring method during Self-Tapping practice in order to produce highly natural translation.

Moreover, the unnatural translation example was provided in Table 7.

Table 7. Unnatural Translation

ST Hubungan Kinerja Perawat Dengan Kepuasan Pasien Di Ruang Rawat Inap RSUD dr. R. Goeteng Taroenadibrata Kabupaten Purbalingga Tahun 2019

TT The Relationship The Performance of a Nurse With Satisfaction of Patients in Inpatient Rooms Local Public Hospital Dr. R. Goeteng Taroenadibrata Kabupaten Purbalingga Year 2019
Based on Table 7, at glance, the title of the abstract was unnatural for English as the target language which were caused by the terminologies that were not naturally rendered and also the grammatical structure that was carelessly composed. With regard to the terminologies used in the sentence, there were some words that were transferred natural in the target language, such as hubungan into the relationship, kinerja perawat into the performance of nurse, and kepuasan pasien into satisfaction of patients. However, some terminologies were needed to be revised in the target language such as inpatient rooms into inpatient wards (ward is used in referring a suite of rooms shared by patients in a hospital) and also Local Public Hospital into Regional Public Hospital since the concept would bring different perception for the target readers. There was also a terminology kabupaten that was left by the translator without any change that was supposed to be rendered into target language. This could give more meaning toward the sentence in the target language.

In terms of grammatical structure, the sentence was arranged ungrammatically which resulted in meaningless sentence. The sentence which acted as the title of the research could not deliver the function to the target readers and only created confusion. At first, the translator should focus on the pair of prepositions utilized within the sentence, such as Hubungan Kinerja Perawat Dengan Kepuasan Pasien which was translated into The Relationship The Performance of a Nurse With Satisfaction of Patients. Discussing about relationship, the pair of prepositions that was supposed to be used was ...between... and... in order to create natural sentence which align with English grammar because it really helps to create meaning. The translation was supposed to be replace by The Relationship between the Performance of a Nurse and the Satisfaction of Patients in Impatient Wards of Dr. R. Goeteng Taroenadibrata Regional Public Hospital Purbalingga Regency Year 2019. 


\section{Translation Acceptability}

The acceptability of the translation focused on how well the translation text could be accepted by the target readers. According to Nababan (2012) acceptability of the translation text is represented by how natural the translation is. Moreover, the characteristics of translation acceptability is when the terminologies are usual and familiar to the addressed readers which is proved by the sentence elements that already aligned with the target language rules. Although the terminologies utilized in the translation have been accurately rendered; however, it does not mean that the translation is acceptable because it has different meaning in the sentence level. The result of acceptability analysis was provided in Figure 3.

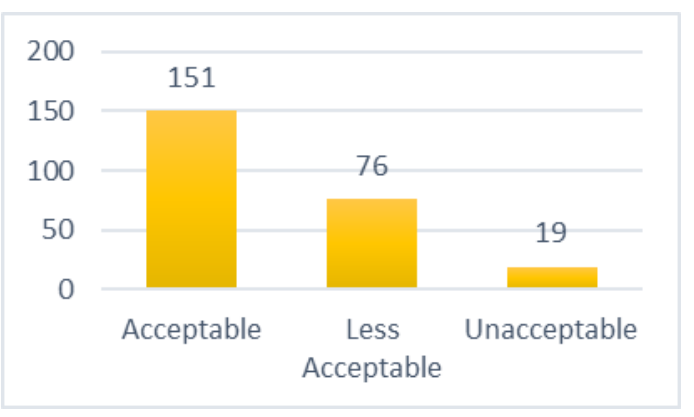

Figure 3. Translation Acceptability

Based on the data presented in Figure 3, it could be seen that more than 150 occurrences of the research translation that were categorized as acceptable translation which also indicated that most of the abstract translation had already been in accordance with target language rules. There was also some translation which categorized as less acceptable as many as 76 times. Meanwhile, unacceptable translation only occurred 19 times. This indicated that most of the research abstract translation was regarded as acceptable translation. Thus, the example of acceptable translation was provided in Table 8 .
Table 8. Acceptable Translation

ST Senam memiliki banyak manfaat seperti menurunkan tekanan darah, memperbaiki denyut nadi dan memperkuat fungsi jantung.

TT Gymnastics has many benefits such as lowering blood pressure, improving pulse rate and strengthening heart function.

On the presented Table 8, the medical terminologies were rendered by appropriate choice of dictions in the target language which made the translation became acceptable and generally familiar, such as senam into gymnastics, tekanan darah into blood pressure, denyut nadi into pulse rate and fungsi jantung into heart function. Those terminologies were generally utilized in the medical field that made them to be easily recognized and accepted by the target readers. Thus, the terminologies within the target language were recognizable for the target readers because of it had already followed the grammatical rules of target language.

With regard to the grammatical structure, the sentence was well translated following the parallel structure in which the noun phrases were arranged using similar forms of gerund verb-ing, such as lowering blood pressure, improving pulse rate and strengthening heart function. Hence, this sentence was categorized as acceptable translation. There was only a small problem in punctuation coma (,) which should be put before the words such as.

In addition, the example of less acceptable translation was presented in Table 9.

Table 9. Less Accetable Translation

\begin{tabular}{|c|c|}
\hline ST & $\begin{array}{l}\text { Senam jantung sehat efektif dapat } \\
\text { menurunkan tekanan darah di } \\
\text { Perkumpulan Jantung Sehat }\end{array}$ \\
\hline TT & $\begin{array}{l}\text { Healthy heart exercises can effective } \\
\text { reduce blood pressure in healthy heart } \\
\text { association RSUD Prof. Dr. Margono } \\
\text { Soekarjo Purwokerto. }\end{array}$ \\
\hline
\end{tabular}

Based on Table 9, there were some terminologies that were generally used in the target language, such as tekanan darah into blood 
pressure that was universally used and perkumpulan jantung sehat into healthy heart association that was transferred literally in English. However, the translation of senam jantung sehat was translated inconsistently into healthy heart exercises which had been translated into healthy heart gymnastics in the previous sentences. This condition supported the status of less acceptable for the translation because the terminology used in the abstract should be consistent and easy to be grasped by the target readers. However, there was a mistake that was made by the translator by adding the word RSUD Prof. Dr. Margono Soekarjo Purwokerto. The abbreviation of RSUD could be replaced either by the word hospital or Regional Public Hospital. Hence, the translation was categorized as less acceptable translation.

In regard to grammatical structure of the sentence, there was a mistake created by the translator in rendering the meaning of the sentence by means of inappropriate diction. The word efektif which acted as adverb was translated into adjective effective which was supposed to be rendered into effectively following the form of the source language form. Hence, the sentence senam jantung sehat efektif dapat menurunkan tekanan darah di Perkumpulan Jantung Sehat was supposed to be translated into healthy heart gymnastics can effectively reduce blood pressure in healthy heart association Prof. Dr. Margono Soekarjo Regional Public Hospital Purwokerto in order to achieve acceptable translation. Moreover, regarding to the function of the sentence, the sentence was arranged as recommendation part of the research abstract which still possessed its function in the target language.

Furthermore, the example of unacceptable translation was provided in Table 10.

Table 10. Unacceptable Translation

ST Penelitian ini bertujuan untuk mengetahui gambaran colony bacteria pada seragam perawat di RSUD dr. R. Goeteng Taroenadibrata Purbalingga.

TT The purpose of this research is to description the colony bacteria at nurses's uniform at $\mathrm{dr}$.

R. Goeteng Taroenadibrata Public Hospital Purbalingga.
On the presented Table 10, the purpose of the research was arranged by inacceptable translation in the target language. In terms of terminology, there were some words that were not appropriately transferred in the target language, such as mengetahui into description, gambaran colony bacteria into the colony bacteria, seragam perawat into nurses's uniform. Those terminologies were not usually used and did not equivalent toward the source language that created the translation became inacceptable. Although, there was only one terminology that had close meaning with the source language $d i$ RSUD dr. R. Goeteng Taroenadibrata Purbalingga which was translated into $d r$. $R$. Goeteng Taroenadibrata Public Hospital Purbalingga, it did not change the status of unacceptability of the translation. The term public hospital has close meaning as Regional Public Hospital in term of universality of medical terminology, while the name of the hospital was kept untranslated because it was the proper name.

In addition, in term of grammatical structure, the sentence was provided in the present tense which was supposed to be arranged by past tense since the research had been done before. Furthermore, there was no verb to describe the function of the sentence as the purpose of the research. Thus, the sentence penelitian ini bertujuan untuk mengetahui gambaran colony bacteria pada seragam perawat di RSUD $d r$. $R$. Goeteng Taroenadibrata Purbalingga could be appropriately rendered into the purpose of this research was to find out the bacteria colony description on nurse uniform at $d r$. $R$. Goeteng Taroenadibrata Regional Public Hospital Purbalingga in order to achieve the acceptable translation category.

\section{Translation Readability}

Translation readability refers to the comprehensibility of the content within the text. According to Nababan (2012) the translation text is regarded to have high readability when the content is comprehensible, although there are some errors of style and/or of spelling and if certain words are missing, or are badly translated, yet close to the target language. In this study, the readability of 20 research abstract 
texts were possessing the various kinds of readability levels as provided in the figure

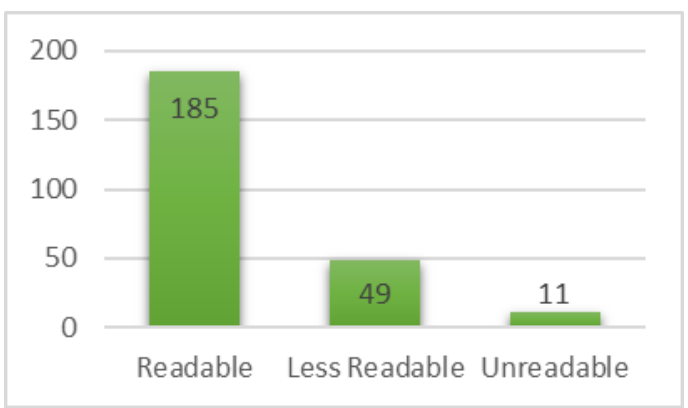

Figure 4. Translation Readability

Based on Figure 4, most of the translation was readable which was proved by the total occurrences 185 for readable translation. This was represented that most of the research abstract translation had already been easy to be comprehended by the target readers. The example of readable translation was presented in Table 11.

Table 11. Readable Translation

ST Hasil uji statistik menunjukan ada
hubungan antara stimulasi dengan perkembangan anak usia 3-5 tahun di PAUD Insan Mentari ( $p$-value $=0,028$ ) dan tidak ada hubungan antara status gizi dengan perkembangan anak usia 3-5 tahun di PAUD Insan Mentari ( $\mathrm{p}$-value = 0,311).

TT Statistical test results show that there is a correlation between stimulation and the development of children 3-5 years old in ECE Insan Mentari Banyumas ( $p$-value = 0,028 ) and there is no correlation between nutritional status and children development of aged 3-5 years in ECE Insan Mentari Banyumas ( $p$-value = $0,311)$.

From Table 11, it could be seen that the terminologies utilized in the sentence that were rendered from the source text into target text were comprehensible by the target readers, such as stimulasi into stimulation, PAUD (Pendidikan Anak Usia Dini) into ECE (Early Childhood Education), status gizi into nutritional status, and perkembangan anak into children development. Those terminologies utilized in the target language had already served to the readability of the sentence that made the meaning within the sentence become easy to be comprehended. There was also a proper name Insan Mentari which was left by the translator as the identity of the place that was also added by the name of the town Banyumas as the location of the school.

However, in terms of the grammatical structure of the text, the translator tended to use the present tense which was supposed to be changed into past tense as the research had been done in the past. Although, there was only few errors in terms of tense usage, the content of the sentence had already been comprehensible for the target readers. Hence, if the tense was changed into past tense, it would be perfectly readable.

Moreover, the example of less readable translation was provided in Table 12.

Table 12. Less Readable Translation

\begin{tabular}{ll}
\hline ST & Tujuan penelitian untuk mengetahui \\
efektivitas senam jantung sehat terhadap \\
penurunan tekanan darah pada lansia di \\
perkumpulan jantung sehat RSUD Prof. \\
Dr. Margono Soekarjo Purwokerto. \\
\hline TT \\
The purpose of this study was to \\
determined the effectiveness of healthy \\
heart gymnastics against the reduction of \\
blood pressure in the elderly in the healthy \\
heart association of RSUD Prof. Dr. \\
Margono Soekarjo Purwokerto.
\end{tabular}

Based on Table 12, the sentence was categorized as having less readable translation which were proved by utilization of terminologies in the target language and also the grammatical structure where the meaning resided. Some of the medical terminologies had successfully rendered into target text, such as senam jantung sehat into healthy heart gymnastics, penurunan tekanan darah into reduction of blood pressure, lansia into elderly, and perkumpulan jantung sehat into the healthy heart association. Those medical terminology translations supported the level of readability in the target 
language. However, there was also translation mistake in rendering the medical terminologies into target language, such as RSUD into RSUD which was supposed to be rendered as Regional Public Hospital. Without mentioning the term hospital, the readers would need more time to comprehend the meaning of the terminology. Moreover, the proper name of the hospital was left as it was, since proper name was supposed not to be translated which might gave different perception toward the readers. Thus, the term Prof. Dr. Margono Soekarjo Purwokerto was left untranslated as it was the name of the hospital.

In regard to the grammatical structure of the sentence, the translator seemed to forget the change of the verb when it functioned as infinitive. The word to determined should be replaced by the word to determine. In addition, there was also a revision which could be made in term of preposition used in the translation, such as the term pada could be replaced by on Furthermore, the sentence tujuan penelitian untuk mengetahui efektivitas senam jantung sehat terhadap penurunan tekanan darah pada lansia di perkumpulan jantung sehat RSUD Prof. Dr. Margono Soekarjo Purwokerto would be appropriately translated into the purpose of the study was to determine the effectiveness of healthy heart gymnastics against the reduction of blood pressure on the elderly in the healthy heart association of Prof. Dr. Margono Regional Public Hospital Soekarjo Purwokerto.

In addition, the example of unreadable translation was presented in Table 13.

Table 13. Unreadable Translation

ST Survey kepuasan pasien, ada tiga hal yang mungkin muncul dari pengukuran kinerja perawat yaitu kinerja sama dengan harapan pasien, kinerja lebih besar dari harapan pasien, atau kinerja lebih kecil dari harapan pasien.

TT Patient satisfaction survey, there are three things that might be occurred nurse performance of the measurement of the performance of the same in the hope of patients, the performance of greater than hope patients, or the performance of smaller than hope patients.
Based on Table 13, there was some mistakes which made the translation was categorized into unreadable translation. The translator did not really comprehend the source text that resulted in the difficulties of the sentence meaning to be grasped. It could be seen that some medical terminologies from the source language had already been rendered successfully into target text, such as survey kepuasan pasien into patient satisfactory survey, kinerja perawat into nurse performance. Yet, there were some mistakes also in the translation of medical terminologies in the target language, such as harapan pasien into hope patient and pengukuran kinerja perawat into nurse performance of the measurement.

Furthermore, in terms of grammatical structure, the mistake happened as it really affected the meaning of the sentence. The translation was arranged without considering the grammatical structure of the sentence in the target language as the words seemed to be randomly placed in the sentence. The sentence survey kepuasan pasien, ada tiga hal yang mungkin muncul dari pengukuran kinerja perawat yaitu kinerja sama dengan harapan pasien, kinerja lebih besar dari harapan pasien, atau kinerja lebih kecil dari harapan pasien was supposed to be translated into based on patient satisfactory survey, there are three categories that might be occurred form nurse performance measurement, namely: performance is equal with patient hope, performance is higher than patient hope, or performance is lesser than patient hope, in order to achieve readable translation that was easy to be comprehended by the target readers.

\section{Translation Ideology of Abstract Translation}

Translation ideology followed by the translator could be traced by means of the analysis of translation quality assessment. It could be unveiled by the analysis of register (field, tenor and mode) and the genre of the source text in order to find the mismatches between the text and its translation. As the type of the 20 text was the same which functioned as research abstract, translation was possessing the 
same function as it had the same structures and it was put on the same part of a thesis.

\section{Register and Genre}

As the sample of the analysis, a research abstract and its translation were analysed by means of text register. The sample analysis was provided in Table 14.

Table 14. Readable Translation

\begin{tabular}{|c|c|}
\hline \multicolumn{2}{|l|}{ Source Text Register } \\
\hline \multicolumn{2}{|l|}{ Field } \\
\hline Subject Matter & Nursing education \\
\hline Social Action & Specific \\
\hline Tenor & \\
\hline $\begin{array}{l}\text { Author's Provenance } \\
\text { and Stance }\end{array}$ & University students \\
\hline $\begin{array}{l}\text { Social } \\
\text { Relationship }\end{array}$ & Asymmetrical \\
\hline $\begin{array}{l}\text { Relationship } \\
\text { Social Attitude }\end{array}$ & Formal \\
\hline Mode & \\
\hline Medium & Simple \\
\hline Participation & Simple \\
\hline Source Text Genre & Nursing Academic \\
\hline Source Text Function & Interpersonal \\
\hline
\end{tabular}

On the Table 14, it showed that field that dealt with the nature of social action is taking place was divided into two parts, namely subject matter and social action. The research abstract text presented the summary of the summary of a thesis research in the field of nursing education. With regard to the research abstract text no 1 , the text discussed the study about relationship between dietary habit and hypertension on the elderly at Baturaden II Public Health Centre in Banyumas Regency. The text was composed by the introduction of hypertension and the causes in relation with dietary habit. Thus, the writer described the characteristics of the study, such as the purpose, methodology and the result of the analysis. Furthermore, the result was provided along with the supporting data, such as the sex, educational level, dietary habit status, and blood pressure. At the end, the keywords were attached mentioning 3 keywords to help the other researcher finding the similar field of study as reference. In term of lexical means, the clinical and medical words were utilized within the text as represented in the title of the research abstract text, such as eating pattern, elderly, hypertension, and Health Centre. As a summary of a research, there were some research technical phrases used in the text, such as the purpose of the study, respondents, descriptive correlational method, and analysis. As academic text, there was not any use of collocation and idiomatic expression within the sentence. With regard to the syntactic means of the text, it was dominated by long sentences with complex structures throughout the text, such as diet is closely related to the incidence of hypertension, because what we eat affects the occurrence of hypertension. The writer mostly began the sentence by using noun and noun phrase such as, prevention of hypertension and unhealthy eating patterns. The writer also made a strong cohesion between sentences through the use of repetitive words, such as diet, blood pressure and elderly.

In term of tenor, the writer of the text is nursing students from bachelor / undergraduate degree program in Harapan Bangsa University located in Purwokerto Academic Year 2018 and 2019. Those who have finished their study are required to conduct a research in medical field. The research is composed and supervised by two supervisors to help them write a good research thesis. As academic research, the thesis is written in formal language without any emotional interference. As one of the elements of research, abstract text functioned as a summary of the research. It is written as a small short version of the thesis which also consists of research elements, such as: title, introduction, aims, methods, results/discussion, conclusion and recommendation. Once the thesis done, the students are examined in a seminar to present their research report. Hence, the writer presence as well as the two advisors were mentioned after the title of the research abstract, such as Dewi Lantasih, Indri Heri Susanti, Wasis Eko Kurniawan indicating that the research was written by the student as well as the lecturer of university. The writer of the research abstract text did not mention emotional and intellectual stance, because the text was composed formally. The 
social role relationship between the addresser and the addressee of the thesis research abstract written by nursing students is asymmetrical because the nursing students as the author of the abstract and publish the abstract text for the general readers, particularly for the further research in clinical field.

In regard to mode, the medium of the text was simple because the text was basically to be read. According to House (1997), an emic text is one which is determined by text-immanent criteria, and etic text is one which is determined through text-transcending means. Thus, research abstract texts, and specifically text under study is etic because the writer of the research abstract compose the text as the summary of the research that has been done before. Since the research abstract text is based on the scientific research, the abstract text is written objectively based on the scientific study. There was no any dialogic nor conversational parts in the text which indicated that the text was monologue format. Regarding to the genre, Research abstract text is categorized as special genre text which presents either the summary of a thesis or a report of a research based on the field of the research. Nursing research abstract is composed by using medical, technical and clinical terminologies. As the summary of a research, nursing abstract text is written as small version of the research by containing generic structure of a research, such as title of the research, background, aims, methods, results and conclusion and recommendation. In order to accomplish its goal of informing the readers about the whole research in a short text, research abstract retain its unique approach of using concise description of the whole research.

Meanwhile, the function of this text is interpersonal based on the genre of the research abstract. The writer's intention is to give a glimpse of information about the research based on the result and discussion within the research. Through the abstract, the students want to share and communicate the research experience as well as the personal recommendation based on the findings. The title functions as the same as the title of the research informing the readers about the matter being examined. Thus, the introduction is presented as a bridge to bring the readers about the topic and the problems to be solved as elaborated in the aims why the research is conducted. Moreover, the methodology is simply stated about how the research is conducted as well as the analysis framework. Furthermore, the result of the analysis is provided elaborated by the numerical proof as well as the description of the result. In addition, the conclusion is also stated concisely. Finally, the recommendation is made by the writer of the research as the personal point of view based on the findings for the sake of the further research as the research novelty. At the end of the abstract, generally the writer also put some keywords of the research to help the readers to find the reference. With regard to the nursing research abstract in Harapan Bangsa University, the students write the abstract as the second page of the thesis after the title. It is intended to help the readers to easily grasp the whole research in just only one page without going too far. The research abstract of nursing students is written based on the scientific experience on clinical field as the requirement of graduation. It also gives benefit for the other researchers to develop the new research.

With regard to the comparison of the original and the translation of research abstract, the research abstract of nursing student is translated in Indonesian into English by the students themselves as stated in the declaration of originality of the thesis mentioning that the students are responsible in conducting and writing the research paper as well as the translation of the abstract text. On the aspect of field, there were some lexical mismatches because the formality of the words was reduced because of the process of translation, such as pendidikan dasar into basic education. On the aspect of tenor, the social relationship was maintained because there were no changes of the personal pronoun in the translation, such as kita into we. As a result, the social role relationship and the social attitude were conveyed well in the target language. On the aspect of mode, there were lexical mismatches in the medium because 
some of the colloquial words were translated informally into English, such as pola makan into diet. Moreover, the translator seemed to be inconsistent in translating the nursing terminology, such as pola makan into eating patterns and diet indicating that the translator did not confident in rendering the terminology. Furthermore, the mismatches between the research abstract text and the translation happened in the area of mode that need to be revised. It could be argued that the research abstract text held nearly the same function that was ideational despite some changes which did not change the whole message although some errors occurred (Maisa, 2018; Muchtar and Kembaren, 2018; and Nafisah et al., 2019).

Meanwhile, the accuracy of the translation was dominated by the accurate replacement of the words, phrases, and the sentence in nursing field. It turned out that the meaning conveyed within the source text was possessing the same information as in the source text. As stated by Larson (1984) that the meaning between the source text and target text is simply correct. However, some revision was needed because some of the translation only conveyed some of the content accurately. Furthermore, it also turned out that a few numbers of the translation failed to convey the same information as the result of inaccurate translation.

On the translation naturalness, the research abstract translation showed that they were dominated by natural and highly natural. This meant that most of the meaning within the translation was clearly expressed in the target language. The terminologies utilized in the translation mostly did not create any ambiguous meaning toward the target readers. The grammatical structure showed good arrangement as it could clearly conveyed the source language meaning into the target language. In line with $\mathrm{Nida}$ (1964, p.167) mentioned that the naturalness of translation was highly influenced by the lexical and grammatical aspects of a sentence. However, it was also found that some of the translation of research abstract were considered less natural and unnatural in the target readers. This indicated that some of the words and sentences rendered from the source text were responded differently by the target readers. This is in line with Putranti (2018) that the respond between the source language reader and target language reader toward the translation might be different because even the correct words and sentence are expected to express the message of source language into the target language, the message would not be responded substantially the same manner as the source language readers.

With regard to the acceptability of the translation, it turned out that most of the research abstract translation showed acceptable category which held more than $50 \%$ of the whole data. This finding indicated that most of the translation had utilized usual terminologies and also had followed the English grammatical rules. The translator had successfully rendered the terminologies clearly to the target readers and made the translation text acceptable for the target readers. Therefore, most of the translation was understandable for the target readers which was proved by familiarity of the terminologies and also well-application of the grammatical rules. However, it was also found that some of the translation was categorized as less natural and unnatural translation. If a translation is accurate in terms of its content or message, the translation will be rejected by the target reader if the method of disclosure is contrary to the rules, norms and culture of the target language (Nababan, 2012; Putranti, 2018; and Prafitasari et al., 2019). Therefore, acceptability of translation was considered to have a close relationship between the translation and how the target reader accepts it. As mentioned by Sutopo (2019) mentioned that the accurate translation cannot guarantee whether the translation had a good quality, instead the acceptability of the translation was also determined by the familiarity of the translation in the target language by the target readers.

In regard to the readability of the translation, the research abstract translation was also mostly readable as most of the data reached the category of readable translation. It indicated 
that most of the words, phrases and the sentences were rendered clearly and easy to be comprehended without any difficulties by the target readers by means of only once reading. However, there was still some revision needed in the translation to improve its readability of the translation since there were also some less readable translation which need more understanding and reading activity more than once to comprehend the translation. As mentioned by Larson in Hartono (2016) that the choice of diction, structure and organization of sentences, spelling and even the punctuation influence the level of readability of the translation. Moreover, there was also found a few findings that were considered unreadable in the target language. Although some of the terminologies within a sentence had been identified as readable translation, the understanding about the meaning of the sentence also constituted to the readability of the translation. The finding also turned out that there were a few unreadable translations found in the translation of research abstract which made the target readers hard to comprehend the translation. Some of the findings indicated that it was caused by the difference between the sentence arrangement and also the meaning conveyed. It was indicated that the translators sometimes failed to comprehend the text in the target language. This is in line with Sutopo (2019) stated that a translator needs to understand the concept of readability both of the source language and also target language in order to be able to produce well translation work.

Furthermore, the comparative analysis of research abstracts and its translation was leading to the ideology followed by the translators in rendering the text. Through the analysis of register and genre, the research abstract texts were rendered overtly by the translator. It turned out that the translator was preferred to tie to the source language, community and culture which was represented by the literal translation utilized by the translator and also source text cultures that were brought to the target language. The words, phrases and sentence employed by the translator in rendering the research abstract text were accurate, natural, acceptable and readable for target language readers although there were some mismatches between the source language and target language. There were some overtly erroneous errors occurred in the translation of research abstract text which was dominated by slight change of meaning and grammatical mismatches. The error was also caused by the untranslated elements, omission and addition in the target language. With regard to the function of the research abstract text, the translator had already kept equivalent in the target language which was represented by the similarity of register and the genre of the text between the text and its translation. The research abstract and its translation still possessed the same purpose that was passing on the essential parts of the texts which was addressed for nursing field. This is in line with Shakernia (2014) stated that overt translation is used when the text was intended for special purposes. Furthermore, the information resided within the research abstract was not covered by the translator instead of transferred as it was in the source language. Therefore, the research abstract texts were rendered following the overt translation than covert translation. This was in line with House (2015, p. 68) abstract text was translated overtly in the target text, because the most essential facts from the source language were only passed on to the target language.

\section{CONCLUSION}

Based on the analysis of the study, the accuracy level of research abstract translation still belonged to accurate translation and although some revisions were considerably needed. Some of the information within the source text was accurately rendered into the target text, while some of meaning within the translation were missed in the target language. In term of naturalness, most of the research abstract translation was possessing high level of naturalness which also referred that the translation was fully understandable for target readers. On the accuracy aspect, it did not 
merely affect the acceptability of the translation, because the familiarity of the language also determined the acceptability. Therefore, the translation had been in accordance with the rules, norms and culture within the target text that was easily understood and acceptable in the target language.

Furthermore, the analysis of ideology followed by the translator of research abstract was overt translation. The result showed that the register and genre of the research abstract and its translation were kept equivalent and holding the same purposes. Thus, translation was tied to the source language including the community and its culture. Therefore, the ideology followed by nursing students in rendering the research abstract translation was overt translation. Although there were some erroneous errors found, it was dominated by slight change of meaning in the target language which need some replacement of the dictions.

For further research, it is expected that the future research could examine the translation quality of various kinds of text by means of various kinds of translation quality assessment perspective. Since this study only focused on the research abstract from nursing department, it is better if the future research could also compare the quality of the translation work done by other field of study.

\section{REFERENCES}

Admiati, A., \& Hartono, R. (2019). Translation quality of idiomatic expressions in "lenka kripac's \& quot; song lyrics from English into Indonesian. Rainbow: Journal of Literature, Linguistics and Cultural Studies, 8(2), 41-51.

Arono, A., \& Nadrah, N. (2019). Students' difficulties in translating English text Journal of Applied Linguistics \& Literature, 4(1), 88-99.

Barezzi, R. H., Nababan, M., \& Santosa, R. (2018). Techniques and quality of 'Civil War: Whose side are you on?' comic translation. LEKSEMA: Jurnal Bahasa dan Sastra, 3(2),
Bassnett, S., \& Mc Guire. (1998). Translation Studies. Methuen \& Co. Ltd.

Bassnett, S. (2002). Translation Studies. London Routledge

Fiederer, R. \& O’brien, S. (2009). Quality and Machine Translation: A realistic objective?. The Journal of Specialised Translation 11, 52-74.

Fitria, T. (2018). Translation techniques found in english to indonesian abstract translation of journal edunomika 2018. ELITE Journal 5(2).

Hartono, R. (2012). Teori penerjemahan (Handbook for translators). Cipta Prima Nusantara Semarang.

Hartono, R., \& Priyatmojo, A. (2016). Translation errors of soft drink product labels from Indonesian into English. The International Seminar Prasasti III (659664). Surakarta: Linguistics Doctoral Program of Sebelas Maret University.

House, J. (2015). Translation quality assessment: past and present. Routledge

House, J. (1997). Translation quality assessment: A model revisited. Narr Print.

Kamil, M. (2014). An analysis of EnglishIndonesian translation quality on twitter web pages (a case study). Journal of English and Education, 2(1), 27-38

Larson, M. L. 1984. Meaning-based Translation. University Press of America Inc.

Maisa, M. (2018). The analysis of translation technique of children story: "Lila, the clumsy witch". Academic Journal Perspective : Education, Language, and Literature, 1(2), 96.

Muchtar, M., \& Kembaren, F. R. (2018). Translation techniques and quality in the English version of Nganting Manuk text. International Journal on Language, Research and Education Studies, 2(2), 195-207.

Nababan, M. R., Nuraeni, A., \& Sumardiono. (2012). Pengembangan model penilaian kualitas terjemahan'. Kajian linguistik dan sastra, 24(1),39-57. 
Nafisah, N., Hartono, R., \& Yuliasri, I. (2019). Translation methods and degree of equivalence in English-Indonesian translation of Leo Tolstoy's "God sees the truth but waits". Rainbow: Journal of Literature, Linguistics and Cultural Studies, 7(2), 1-10.

Napitupulu, S. (2017). Analyzing indonesianenglish abstracts translation in view of translation errors by google translate. International Journal of English Language and Linguistics Research, 5(2), 15-23.

Nida, E. A., \& Taber, C. R. (1982). The theory and practice of translation. E.J Brill.

Prafitasari, A., Nababan, M. R., \& Santosa, R. (2019). An analysis of translation technique and translation quality in poem book entitled Love \& Misadventure. Indonesian Journal of English Language Teaching and Applied Linguistics, 3 (2).
Putranti, A. (2018). Modulation: A translation method to obtain naturalness in target language texts. Journal of Language and Literature, 18(1), 98-101.

Shakernia, S. (2014). Study of Nida's (formal and dynamic equivalence) and Newmark' $\mathrm{s}$ (semantic and communicative translation) translating theories on two short stories. Semantic Scholar.

Sutopo, A. (2019). The Assesment and Reserach on translation studies. Proceedings of the Fifth Prasasti International Seminar on Linguistics (PRASASTI 2019).

Yuliasri, I., \& Allen, P. (2019). Humour loss in the Indonesian translation of Harry Potter and the sorcerer's stone. Indonesian Journal of Applied Linguistics, 9(1).

Zainudin, I. S., ～\& Awal, N. M. (2012). Translation techniques: Problems and solutions. Procedia - Social and Behavioral Sciences, 59, 328-334. 